\title{
PEMODELAN DATA KEMATIAN BAYI DENGAN GEOGRAPHICALLY WEIGHTED NEGATIVE BINOMIAL REGRESSION
}

\author{
Riza F. Ramadhan ${ }^{1}$, Robert Kurniawan ${ }^{2}$ \\ 1,2 Jurusan Komputasi Statistik, Sekolah Tinggi Ilmu Statistik (STIS), Jakarta \\ e-mail: ${ }^{1} 12.7353 @ s t i s . a c . i d,{ }^{2}$ robertk@stis.ac.id
}

DOI: 10.14710/medstat.9.2.95-106

\begin{abstract}
Overdispersion phenomenon and the influence of location or spatial aspect on data are handled using Binomial Geographically Weighted Regression (GWNBR). GWNBR is the best solution to form a regression analysis that is specific to each observation's location. The analysis resulted in parameter value which different from one observation to another between location. The Weighting Matrix Selection is done before doing The GWNBR modeling. Different weighting will resulted in different model. Thus this study aims to investigate the best fit model using infant mortality data that is produced by some kind of weighting such as fixed kernel Gaussian, fixed kernel Bisquare, adaptive kernel Gaussian and adaptive kernal Bisquare in GWNBR modeling. This region study covers all the districts/municipalities in Java because the number of observations are more numerous and have more diverse characteristics. The study shows that out of four kernel functions, infant mortality data in Java2012, the best fit model is produced by fixed kernel Gaussian function. Besides that GWNBR with fixed kernel Gaussian also shows better result than the poisson regression and negative binomial regression for data modeling on infant mortality based on the value of AIC and Deviance.
\end{abstract}

Keywords: GWNBR, infant mortality, fixed gaussian, fixed bisquare, adaptive gaussian, adaptive bisquare.

\section{PENDAHULUAN}

Indonesia melakukan upaya dalam menurunkan angka kematian bayi dan balita, dalam upaya mewujudkan sasaran pembangunan milenium (MDGs) untuk poin ke-4. Unicef Indonesia (2012) menyatakan bahwa pada tahun 1990-an Indonesia menunjukan perkembangan dalam penurunan angka kematian balita bersama dengan komponenkomponennya, angka kematian bayi dan angka kematian bayi baru lahir. Akan tetapi, dalam beberapa tahun terakhir, penurunan angka kematian bayi (AKB) baru lahir tampak terhenti. Jika tren ini berlanjut, Indonesia berkemungkinan tidak mencapai target MDG ke empat. AKB ini merupakan indikator untuk menilai target penurunan angka kematian bayi yang dilihat dari Jumlah Kematian Bayi dibagi dengan Jumlah Kelahiran Hidup. Hubungan jumlah kematian bayi dengan faktor-faktor penyebabnya dapat diketahui salah satunya dengan metode analisis regresi. 
Analisis regresi merupakan salah satu metode untuk menentukan adanya hubungan sebab akibat antara satu variabel dan variabel yang lain. Analisis regresi sendiri sangat luas pemakaiannya karena ada model pada analisis regresi yang dapat digunakan secara baik hanya pada kondisi tertentu. Salah satu contoh kondisinya ketika data variabel respon yang dijumpai adalah data cacah seperti jumlah kematian bayi dengan sebaran Poisson maka regresi Poisson menjadi cocok untuk digunakan. Namun, regresi Poisson mempunyai asumsi yang harus dipenuhi yaitu rata-rata variabel respon harus sama dengan variansinya yang dikenal dengan istilah equidispersi (Dobson dan Barnett, 2008). Namun, dalam kenyataannya tidak semua data cacah ini memiliki nilai rata-rata yang sama dengan variansinya. Giuffre et al. (2011) menyatakan bahwa yang sering terjadi pada data poisson adalah kondisi rata-rata yang lebih kecil dari variansinya atau lebih dikenal dengan istilah overdispersi.

Overdispersi dapat terjadi karena ada data yang berkelompok dalam populasi (McCullagh dan Nelder, 1989). Jika data dalam kelompok tersebut berkorelasi positif maka analisis dengan metode yang mengasumsikan kebebasan antar elemen akan menghasilkan penduga yang underestimate atau varians yang lebih kecil dari nilai sebenarnya (Astuti, 2006). Dari permasalahan overdispersi tersebut maka dibutuhkan model regresi yang lain, karena regresi Poisson menjadi kurang cocok digunakan untuk menganalisis data tersebut.Salah satu regresi yang tidak harus memenuhi asumsi equidispersi pada regresi Poisson adalah regresi Negative Binomial (NB). Regresi ini merupakan salah satu metode campuran poisson-gamma yang distribusi gamma-nya digunakan untuk mengatasi data overdispersi yang terjadi pada regresi Poisson (Hardin dan Hilbe 2007).

Pada dasarnya regresi Poisson maupun regresi Negative Binomial (NB) mempunyai kegunaan untuk menganalisis hubungan antara variabel respon (Y) data cacah dan satu atau lebih variabel penjelas (X). Akan tetapi, metode ini kurang representatif jika diterapkan pada data spasial atau data yang mengandung kondisi geografis (Widodo dkk, 2013). Di dalam penelitannya Afri (2013) dijelaskan bahwa salah satu alat analisis untuk mengatasi kasus data spasial tersebut dikembangkan oleh McMillen dan McDonald tahun 1997 dan model ini dinamai Geoghraphically Weighted Regression (GWR) oleh Fotheringham et al. (2002). Kemudian, untuk kasus penanganan fenomena overdispersi dan pengaruh lokasi atau aspek spasial pada data, penelitian selanjutnya menggunakan Geographically Weighted Binomial Regression (GWNBR).

GWNBR adalah salah satu solusi yang tepat untuk membentuk analisis regresi yang bersifat lokal untuk setiap lokasi pengamatan. Hasil analisisnya adalah nilai-nilai parameternya berlaku hanya pada tiap lokasi pengamatan dan berbeda dengan lokasi lainnya (Rahmawati dan Djuraidah, 2010). GWR merupakan bagian dari analisis spasial yang mempunyai pembobot berdasarkan posisi atau jarak satu lokasi dengan lokasi pengamatan lain. Unsur pembobot tersebut menentukan semakin dekat suatu lokasi, bobot pengaruhnya akan semakin besar.

Pemilihan matriks pembobot dilakukan sebelum masuk untuk pemodelan GWNBR. Berbeda dalam memilih pembobot maka berbeda pula hasil pada model yang dihasilkan. Sehingga dalam penelitian ini bertujuan menginvestigasi model terbaik yang dihasilkan oleh beberapa jenis pembobot diantaranya Kernel Tetap Gaussian, Kernel Tetap Bisquare, Kernel Adaptive Gaussian, dan Kernel Adaptive Bisquare dalam pembentukan model GWNBR untuk data Kematian Bayi. Kemudian pembobot yang menghasilkan model 
terbaik dipilih untuk memodelkan data Kematian Bayi. Model terbaik adalah model yang menghasilkan nilai AIC terkecil (Widarjono, 2007) dan devian terkecil (Afri, 2013)

Afri (2013) menggunakan Model GWNBR untuk Data Kematian Bayi pada tahun 2008 di Jawa Timur. Jumlah kematian bayi adalah kejadian langka yang terjadi pada satuan waktu yang satu daerah dengan daerah lainnya memberikan pengaruh yang berbeda, sehingga variabel-variabel penelitian ini mengacu pada penelitian Afri (2013). Variabel yang didapat kemudian disesuaikan dengan kondisi data yang ada pada tahun 2012 terkait ketersediaan dan kelengkapan data. Kemudian wilayah yang dipilih untuk penelitian ini adalah kabupaten/kota di Pulau Jawa karena jumlah pengamatan lebih banyak dan karakteristik pengamatan lebih beragam.

\section{KAJIAN PUSTAKA}

\subsection{Regresi Poisson}

Regresi Poisson yang melibatkan $n$ pasangan data, variabel respon $\left(\mathrm{Y}_{i}\right)$ dan variabel penjelas $\left(\mathrm{X}_{i}\right)$ dengan $i=1,2,3, \ldots, n$ memiliki hubungan antar variabel. Hubungan tersebut dinyatakan oleh Myers (1990) sebagai berikut:

$$
Y_{i}=\mu_{i}+\varepsilon_{i}
$$

dengan $\varepsilon_{i}$ adalah galat atau error pada pengamatan ke-i dan $\mu_{i}$ adalah nilai harapan dari $\mathrm{Y}_{i}$. Untuk mengetahui variabel $\mathrm{X}_{i}$ maka $\mu_{i}$ dinyatakan sebagai:

$$
\mu_{i}=E\left(Y_{i}\right)=\exp \left(\sum_{j=0}^{p} \beta_{j} x_{i j}\right)
$$

\subsection{Regresi Binomial Negatif}

Regresi binomial negatif merupakan salah satu model regresi terapan dari GLM. Fungsi padat peluang dari sebaran Binomial Negatif (Astuti, 2006) dapat ditulis sebagai berikut:

$$
f(y ; \mu, \varphi)=\frac{\Gamma\left(y+\varphi^{-1}\right)}{\Gamma\left(\varphi^{-1}\right) \mathrm{y} !}\left(\frac{1}{1+\varphi \mu}\right)^{\varphi^{-1}}\left(\frac{\varphi \mu}{1+\varphi \mu}\right)^{y}
$$

dengan rata-rata dan varians Binomial Negatif dinyatakan dalam bentuk:

$$
E(y)=\mu \text { dan } \operatorname{Var}(y)=\mu+\varphi \mu^{2}
$$

\subsection{Keragaman Spasial}

Keragaman spasial adalah fenomena dalam model spasial. Karena keragaman spasial terjadi karena adanya pengaruh dari perbedaan karakteristik wilayah dan letak geografi antar wilayah pengamatan (Charlton dan Fotteringham, 2009). Variansi spasial ini dapat diketahui dengan menggunakan pengujian Breusch-Pagan (BP) (Anselin 1988) dngan observasinya berupa wilayah. Hipotesisnya adalah:

$$
\begin{aligned}
& H_{0}: \sigma_{1}^{2}=\sigma_{2}^{2}=\ldots=\sigma_{k}^{2}=\sigma^{2} \text { (antarlokasi mempunyai variansi yang sama) } \\
& H_{1}: \sigma_{i}^{2} \neq \sigma^{2} \text { Minimal ada satu yang tidak sama (tidak terdapat variansi antarlokasi) }
\end{aligned}
$$


Statistik Uji:

$$
B P=\left(\frac{1}{2}\right) f^{T} Z\left(Z^{T} Z\right)^{-1} Z^{T} f \square \chi_{(k)}^{2}
$$

dengan

$$
\boldsymbol{f}=\left(f_{1}, f_{2}, \ldots, f_{n}\right)^{T}, f_{\mathrm{i}}=\left(\frac{e_{\mathrm{i}}^{2}}{\sigma^{2}}-1\right), \text { dan } e_{\mathrm{i}}=y_{\mathrm{i}}-\hat{y}_{\mathrm{i}}
$$

Z : Matriks dengan ukuran $n(k+1)$, berisi vektor yang sudah di normal bakukan (z) untuk setiap pengamatan

$e_{i}^{2} \quad$ : Kuadrat sisaan untuk pengamatan ke-i

$\sigma^{2}$ : Ragam dari y

Kaidah pengambilan keputusan untuk pengujian keragaman spasial menggunakan BP, yaitu jika nilai $p$-value nya kurang dari tingkat signifikansi $(\alpha) 5 \%$, maka kesimpulannya menolak $\mathrm{H}_{0}$.

\subsection{Fungsi Kernel}

Terdapat dua jenis fungsi Kernel dalam GWR, yaitu fungsi Kernel tetap atau Fixed Kernel dan fungsi Kernel Adaptif atau Adaptive Kernel (Fotheringham et al., 2002).

Fungsi Fixed Spatial Kernel memiliki bandwith (b) yang sama pada setiap titik lokasi pengamatan. Dua jenis fungsi kernel tetap yang digunakan dalam GWR adalah

1. Fungsi Kernel Tetap Gaussian

$$
w_{i j}=\exp \left[-\frac{1}{2}\left(\frac{d_{i j}}{b}\right)^{2}\right]
$$

2. Fungsi Kernel Tetap Bi-square

$$
w_{i j}=\left\{\begin{array}{c}
{\left[1-\left(\frac{d_{i j}}{b}\right)^{2}\right]^{2} \text {, jika } d_{i j}<b} \\
0, \text { lainnya }
\end{array}\right.
$$

Fungsi Adaptive Spatial Kernel memiliki bandwidth yang berbeda untuk setiap titik lokasi pengamatan. Dua jenis fungsi kernel adaptif dalam GWR yaitu:

1. Fungsi Kernel Adaptif Gaussian

$$
w_{i j}=\exp \left[-\frac{1}{2}\left(\frac{d_{i j}}{b_{i(q)}}\right)^{2}\right]
$$


2. Fungsi Kernel Adaptif Bi-square

$$
w_{i j}=\left\{\begin{array}{c}
{\left[1-\left(\frac{d_{i j}}{b_{i(q)}}\right)^{2}\right]^{2}, \text { jika } d_{i j}<b} \\
0, \text { lainnya }
\end{array}\right.
$$

dengan $\quad d_{i j}=\sqrt{\left(u_{i}-u_{j}\right)^{2}+\left(v_{i}-v_{j}\right)^{2}}$ adalah jarak euclidean antara titik lokasi pengamatan ke-i dan titik lokasi pengamatan ke-j (Fotheringham et al., 2002).

Pemilihan bandwidth optiomum salah satunya adalah Akaike Information Criterion (AIC). Menurut Akaike (1974) fungsi AIC adalah:

$$
A I C=2 k-2 \log (L)
$$

dengan $k$ adalah banyaknya parameter penduga pada model dan $L$ merupakan fungsi Likelihood dari model. Proses pemilihan lebar bandwidth optimum menggunakan teknik Golden Section Search. Teknik ini dilakukan secara iterasi dengan mengevaluasi nilai AIC terkecil pada interval jarak minimum dan maksimum lokasi pengamatan sehingga diperoleh nilai AIC minimum.

\subsection{Geographically Weighted Negative Binomial Regression}

Model Geographically Weighted Negative Binomial Regression (GWNBR) adalah salah satu metode yang cukup efektif menduga data yang memiliki spasial heterogenitas untuk data cacah yang memiliki overdispersi (Widodo dkk, 2013). Model GWNBR akan menghasilkan parameter lokal dengan masing-masing lokasi akan memiliki parameter berbeda. Model GWNBR dapat dirumuskan sebagai berikut:

$$
\boldsymbol{y}_{\boldsymbol{i}} \square \boldsymbol{N B}\left[\exp \left(\boldsymbol{x}_{\boldsymbol{i}}^{\boldsymbol{T}} \beta\left(\boldsymbol{u}_{\boldsymbol{i}}, \boldsymbol{v}_{\boldsymbol{i}}\right)\right), \varphi\left(\boldsymbol{u}_{\boldsymbol{i}}, \boldsymbol{v}_{\boldsymbol{i}}\right)\right], i=1,2, \ldots, n
$$

Sehingga fungsi padat peluang dapat ditulis dalam bentuk persamaan berikut:

$$
f\left(y_{i} ; \mu_{i}, \varphi\left(u_{i}, v_{i}\right)\right)=\frac{\Gamma\left(y_{i}+\varphi^{-1}\right)}{\Gamma\left(\varphi^{-1}\right) y_{i} !}\left(\frac{1}{1+\varphi \mu_{i}}\right)^{\varphi^{-1}}\left(\frac{\varphi \mu_{i}}{1+\varphi \mu_{i}}\right)^{y_{i}}
$$

dengan

$$
\begin{array}{ll}
y_{i} & : \text { Nilai observasi respon ke-i } \\
\mu_{\mathrm{i}} & : \exp \left(\boldsymbol{x}_{\boldsymbol{i}}^{T} \beta\left(\boldsymbol{u}_{\boldsymbol{i}}, \boldsymbol{v}_{\boldsymbol{i}}\right)\right) \text { (rata-rata untuk setiap lokasi }\left(u_{i}, v_{i}\right) \\
\varphi\left(u_{i}, v_{i}\right) & : \text { parameter dispersi untuk setiap lokasi }\left(u_{i}, v_{i}\right)
\end{array}
$$

\section{METODOLOGI PENELITIAN}

\subsection{Variabel Penelitian dan Sumber Data}

Variabel-variabel yang digunakan antara lain : Jumlah kematian bayi (Y), rata-rata sarana kesehatan (X1), rasio tenaga kesehatan (X2), persentase keluarga yang anggotanya menjadi buruh tani (X3), jumlah penduduk miskin (X4), jumlah sekolah negeri dan swasta 
(X5), jumlah balita penderita gizi buruk (X6), jumlah bayi yang diberi ASI eksklusif (X7), rasio keluarga yang berada di pemukiman kumuh per 10000 penduduk (X8), dan Jumlah Persalinan oleh tenaga selain medis (X9).

Data yang digunakan adalah data sekunder yang diperoleh melalui Dinas Kesehatan dan Melalui Publikasi BPS pada tahun 2012 dapat dilihat di Tabel 1.

Tabel 1. Rincian Variabel Jumlah Kematian Bayi dan Faktor yang Mempengaruhinya

\begin{tabular}{|c|c|c|c|}
\hline No & Nama Variabel & Simbol & Sumber Data \\
\hline 1. & $\begin{array}{l}\text { Jumlah Kematian Bayi pada tiap } \\
\text { kabupaten/kota di Pulau Jawa } \\
\text { 2012. }\end{array}$ & $\mathrm{Y}$ & $\begin{array}{l}\text { Profil Kesehatan } 2012 \text { Provinsi: } \\
\text { Banten, DKI Jakarta, Jawa Barat, Jawa } \\
\text { Tengah, DI Jogjakarta, Jawa Timur }\end{array}$ \\
\hline 2. & $\begin{array}{l}\text { Rata-rata Sarana Kesehatan } \\
\text { (Puskesmas, Poskesdes, } \\
\text { Posyandu) per desa/kelurahan } \\
\text { tiap kabupaten/kota di Pulau Jawa } \\
2012\end{array}$ & $\mathrm{X} 1$ & $\begin{array}{l}\text { Profil Kesehatan } 2012 \text { Provinsi: Banten, } \\
\text { DKI Jakarta, Jawa Barat, Jawa Tengah, } \\
\text { DI Jogjakarta, Jawa Timur }\end{array}$ \\
\hline 3. & $\begin{array}{l}\text { Rasio Tenaga Kesehatan } \\
\text { puskesmas dan rumah sakit } \\
\text { (Dokter, Bidan, dan Perawat) per } \\
10000 \text { penduduk tiap } \\
\text { kabupaten/kota di Pulau Jawa } \\
2012\end{array}$ & $\mathrm{X} 2$ & $\begin{array}{l}\text { Data Dasar 2012-Dinkes Prov.Jateng } \\
\text { Profil Kesehatan } 2012 \text { Provinsi: } \\
\text { Banten, DKI Jakarta, Jawa Barat, DI } \\
\text { Jogjakarta, Jawa Timur }\end{array}$ \\
\hline 4. & $\begin{array}{l}\text { Persentase keluarga yang } \\
\text { anggotanya menjadi buruh tani } \\
\text { pada tiap kabupaten/kota. }\end{array}$ & X3 & SUSENAS 2012 \\
\hline 5. & $\begin{array}{l}\text { Jumlah Penduduk Miskin (dan } \\
\text { hampir miskin) yang dicakup } \\
\text { ASKESKIN dalam setahun } \\
\text { terakhir pada tiap kabupaten/kota. }\end{array}$ & $\mathrm{X} 4$ & $\begin{array}{l}\text { Data dan Informasi Kemiskinan } \\
\text { kabupaten/kota } 2012\end{array}$ \\
\hline 6. & $\begin{array}{l}\text { Jumlah sekolah negeri dan swasta } \\
\text { (SD, SMP, dan SMA) pada tiap } \\
\text { kabupaten/kota. }\end{array}$ & X5 & $\begin{array}{l}\text { Daerah Dalam Angka 2012: Banten } \\
\text {,DKI Jakarta, Jawa Barat,Jawa } \\
\text { Tengah,DI Jogjakarta,Jawa Timur. }\end{array}$ \\
\hline 7. & $\begin{array}{l}\text { Jumlah balita penderita gizi buruk } \\
\text { pada tiap kabupaten/kota. }\end{array}$ & X6 & $\begin{array}{l}\text { Profil Kesehatan } 2012 \text { Provinsi: } \\
\text { Banten, DKI Jakarta, Jawa Barat, Jawa } \\
\text { Tengah, DI Jogjakarta, Jawa Timur }\end{array}$ \\
\hline 8. & $\begin{array}{l}\text { Jumlah bayi yang diberi ASI } \\
\text { eksklusif pada tiap } \\
\text { kabupaten/kota. }\end{array}$ & $\mathrm{X} 7$ & $\begin{array}{l}\text { Profil Kesehatan } 2012 \text { Provinsi: } \\
\text { Banten, DKI Jakarta, Jawa Barat, Jawa } \\
\text { Tengah, DI Jogjakarta, Jawa Timur }\end{array}$ \\
\hline 9. & $\begin{array}{l}\text { Rasio Keluarga yang berada di } \\
\text { Pemukiman Kumuh per } 10000 \\
\text { penduduk pada tiap } \\
\text { kabupaten/kota }\end{array}$ & X8 & Profil Desa \\
\hline 10. & $\begin{array}{l}\text { Jumlah Persalinan oleh tenaga } \\
\text { selain medis pada tiap } \\
\text { kabupaten/kota. }\end{array}$ & X9 & $\begin{array}{l}\text { Profil Kesehatan } 2012 \text { Provinsi: } \\
\text { Banten, DKI Jakarta, Jawa Barat, Jawa } \\
\text { Tengah, DI Jogjakarta, Jawa Timur }\end{array}$ \\
\hline
\end{tabular}




\subsection{Tahapan Penelitian}

Tahapan penelitian yang digunakan untuk mencapai tujuan penelitian ini adalah sebagai berikut:

1. Memeriksa distribusi variabel respon. Variabel respon yang digunakan adalah data dengan mengikuti distribusi binomial negatif, nilai parameter dari distribusi dinyatakan dalam bentuk $\mathrm{E}(\mathrm{Y})=\mu$ dan $\mathrm{V}(\mathrm{Y})=\mu+\varphi \mu^{2}$.

2. Memeriksa adanya overdispersi. Pemeriksaan overdispersi ini bisa didapat dari nilai dispersi pearson Chi-Square atau bisa didapat dari deviance yang dibagi dengan derajat bebasnya diperoleh nilai lebih besar dari 1 (Pratama dan Wulandari, 2015)

3. Memeriksa multikolinearitas. Uji Multikolinearitas digunakan untuk mengetahui ada atau tidaknya penyimpangan pada asumsi klasik yaitu adanya hubungan linear antar variabel penjelas dalam model regresi.

4. Menguji variansi spasial dengan menggunakan uji BP (Breusch-Pagan) . Hipotesis yang digunakan adalah variansi antar pengamatan sama. Keputusan tolak Hipotesis berarti variansi antar lokasi berbeda.

5. Menganalisis data menggunakan GWNBR. Adapun langkah dalam proses GWNBR sebagai berikut.

a. Menghitung matriks jarak euclidean antar pengamatan

b. Menentukan besar bandwidth tiap pengamatan dengan cara Golden Section Search.

d. Mengujikan masing-masing kernel atau matriks pembobot.

e. Menghitung parameter GWNBR dengan metode iterasi Newton Raphson.

6. Membandingkan masing-masing nilai AIC dan Deviance setiap kernel pada model GWNBR kemudian memilih kernel dengan AIC dan Deviance terkecil untuk memodelkan data kematian bayi.

7. Melakukan Interpretasi model yang didapat.

\section{HASIL DAN PEMBAHASAN}

\subsection{Variabel Respon}

Variabel respon yang dipakai adalah data cacah yaitu jumlah kematian bayi dengan nilai terendah adalah 4 dan nilai tertinggi adalah 508. Dengan rata-rata sebesar 166.69 dan varians 11586.64. Adanya keragaman antar wilayah menjadikan variasi yang lebih besar daripada rata-rata atau terjadi overdispersi. Dengan demikian variabel respon berdistribusi Binomial Negatif.

\subsection{Memeriksa Multikolinearitas}

Hasil dari uji VIF pada Tabel 2 menunjukan bahwa variabel penjelas X9 mempunyai nilai lebih dari 10 dan variabel X5 lebih dari 5. Menurut Gujarati (1995) jika VIF lebih dari 10, terjadi multikolinearitas dan jika VIF bernilai 5 sampai dengan 10, memiliki potensi masalah. Sehingga variabel penjelas X9 dan X5 dikeluarkan dari model yang dapat dilihat Tabel 3. 
Tabel 2. Nilai VIF Semua Variabel

\begin{tabular}{cccccccccc}
\hline Var & X1 & X2 & X3 & X4 & X5 & X6 & X7 & X8 & X9 \\
\hline VIF & 1.85 & 2.05 & 3.77 & 3.94 & 9.28 & 2.17 & 2.21 & 1.25 & 10.9 \\
\hline
\end{tabular}

Tabel 3. Nilai VIF Tanpa Variabel X5 dan X9

\begin{tabular}{cccccccc}
\hline Var & X1 & X2 & X3 & X4 & X6 & X7 & X8 \\
\hline VIF & 1.73 & 1.76 & 2.39 & 2.28 & 1.87 & 1.79 & 1.19 \\
\hline
\end{tabular}

\subsection{Memeriksa Keragaman Spasial}

Hasil dari uji diperoleh nilai BP sebesar 45.741 yang nilai peluangnya adalah 9.816e-08. Nilai peluangnya kurang dari tingkat signifikansi 5\%. Cara lain yaitu dengan membandingkan nilai BP dengan $\chi_{(0,05,7)}^{2}=14.06714045$. Antarlokasi mempunyai variansi yang berbeda bila $p$-value $<\alpha$ atau $\mathrm{BP}>\chi_{\chi_{G, k}^{2}}^{2}$ yang artinya menolak $\mathrm{H}_{0}$ atau variansi antar lokasi berbeda.

\subsection{Geographically Weighted Negative Binomial Regression}

a. Matriks Jarak

Jarak yang digunakan adalah jarak euclidean. Jarak ini didapat melalui variabel kordinat masing-masing pengamatan.

b. Bandwidth, AIC dan Deviance

Bandwidth yang diujicobakan untuk kasus ini adalah bandwidthtetap dengan mengevaluasi AIC terkecil dengan teknik golden section search. Pada Tabel 4 nilai AIC terkecil adalah kernel Fixed Gaussian. Bandwidth terpilih adalah 1.754969 (dalam satuan kordinat) atau jika di konversi kira-kira sebesar 194.694 km.

Tabel 4. Bandwidth, AIC, dan Deviance untuk masing-masing Fungsi Kernel pada Model GWNBR

\begin{tabular}{cllll}
\hline No & Fungsi Kernel & \multicolumn{1}{c}{ Bandwidth } & AIC & Deviance \\
\hline 1 & Tetap Gaussian & 1.754969 & 696.5925 & 32.88764 \\
2 & Tetap Bisquare & 4.240107 & 728.3535 & 33.11355 \\
3 & Adaptif Gaussian & 3.830045 (obs 1) & 877.7416 & 34.26246 \\
4 & Adaptif Bisquare & 6.036699 (obs 1) & 752.3044 & 33.27063 \\
\hline
\end{tabular}

Hasil ini ternyata sesuai dengan penelitian Guo, Ma, dan Zhang (2013) yang menyatakan bahwa model GWR akan lebih fit dengan ukuran bandwidth yang lebih kecil kemudian hasil dari fungsi kernel tetap menghasilkan distribusi spasial yang lebih halus dibandingkan dengan fungsi kernel adaptif. Selain itu, penelitian ini juga mempunyai kemiripan hasil dengan penelitian dari Bidanset dan Lombard (2014) yang menyatakan bahwa fungsi tetap gaussian mempunyai AIC paling kecil dibandingkan dengan fungsi lainnya. 
Jika dibandingkan gaussian dengan bisquare, ternyata fungsi bisquare cenderung tidak memperhatikan lagi wilayah yang berada diluar bandwidth-nya. Padahal belum tentu wilayah yang jauh tidak memberikan pengaruh terhadap wilayah penelitian itu sendiri. Berbeda dengan gaussian yang masih memperhatikan wilayah lain yang berada diluar bandwidth-nya karena bandwidth hanya menyatakan pengaruh besar jika wilayah lain ada didalam area bandwidth dan pengaruh kecil jika diluar. Hal ini bisa dilihat pada gambar berikut (Gollini et al., 2015).
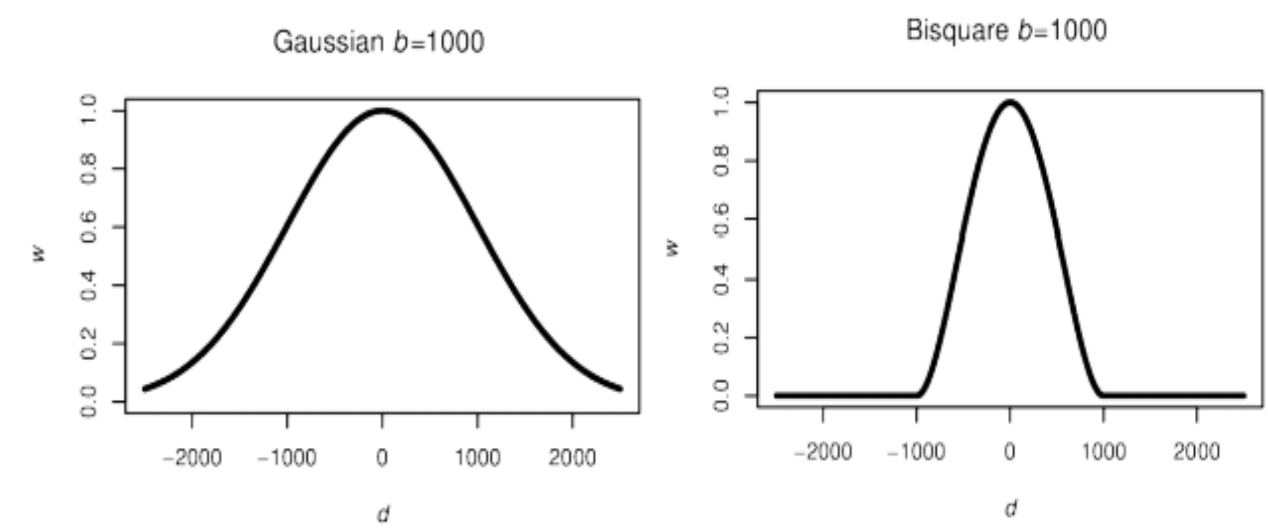

Gambar 1. Plot Fungsi Kernel Gaussian dan Bisquare, dengan Bandwidth $b=1000, w=$ weight, dan $d$ adalah jarak.

c. Matriks Pembobot Spasial

Bandwidth yang terpilih kemudian digunakan untuk mencari matriks pembobot spasial dengan menggunakan kernel tetap Gaussian. Hasilnya berupa matriks $n \times n$, dengan $n$ adalah banyaknya observasi.

d. GWNBR dengan Iterasi Numerik Newton Raphson

Melalui formula iterasi Newton Raphson dengan parameter awal merupakan parameter yang didapat dari regresi binomial negatif. Parameter ini kemudian diiterasi pada tiap pengamatan sampai konvergen sehingga menjadi parameter lokal pengamatan itu sendiri. Parameter yang signifikan dengan taraf nyata 5\% di setiap kabupaten/kota yang telah dikelompokkan dapat dilihat pada Tabel 5.

Pengelompokan pada Tabel 5 bisa juga disajikan dalam bentuk peta. Pemetaannya terdapat pada Gambar 2. Pada gambar tersebut warna biru merupakan kelompok 1. Warna hijau merupakan kelompok 2. Warna kuning merupakan kelompok 3. Warna orange merupakan kelompok 4. Warna merah merupakan kelompok 6.

Selanjutnya hasil penilaian terhadap Model GWNBR dilakukan berdasar nilai devian dan AIC terkecil. Hasil perhitungan menunjukan devian GWNBR senilai 32.88764 dan AIC sebesar 696.5925. Jika dibandingkan dengan model regresi Poisson dan model regresi Negatif Binomial, GWNBR kernel tetap Gaussian pada studi kasus kematian bayi lebih bagus. Nilai Devian dan AIC masing-masing model ada pada Tabel 6. 
Tabel 5. Pengelompokan Kabupaten/Kota berdasarkan Variabel yang Signifikan dengan model GWNBR Kernel Tetap Gaussian

\begin{tabular}{|c|c|c|c|c|}
\hline \multicolumn{3}{|c|}{ Kabupaten/Kota } & Kelompok & $\begin{array}{c}\text { Variabel yang } \\
\text { Signifikan }\end{array}$ \\
\hline $\begin{array}{l}\text { Kab. Banjarnegara } \\
\text { Kab. Kebumen } \\
\text { Kab. Purworejo } \\
\text { Kab. Wonosobo } \\
\text { Kab. Magelang } \\
\text { Kab. Boyolali } \\
\text { Kab. Klaten } \\
\text { Kab. Sukoharjo } \\
\text { Kab. Wonogiri } \\
\text { Kab. Karanganyar } \\
\text { Kab. Sragen } \\
\text { Kab. Grobogan } \\
\text { Kab. Rembang } \\
\text { Kab. Pati } \\
\text { Kab. Kudus } \\
\text { Kab. Jepara }\end{array}$ & $\begin{array}{l}\text { Kab. Demak } \\
\text { Kab. Semarang } \\
\text { Kab. Temanggung } \\
\text { Kab. Kendal } \\
\text { Kab. Batang } \\
\text { Kota Magelang } \\
\text { Kota surakarta } \\
\text { Kota salatiga } \\
\text { Kota semarang } \\
\text { Kota pekalongan } \\
\text { Kab. Kulon progo } \\
\text { Kab. Bantul } \\
\text { Kab. Gunung kidul } \\
\text { Kab. Sleman } \\
\text { Kota Yogyakarta }\end{array}$ & $\begin{array}{l}\text { Kab. Pacitan } \\
\text { Kab. Trenggalek } \\
\text { Kab. Tulungagung } \\
\text { Kab. Blitar } \\
\text { Kab. Blora } \\
\text { Kab. Ngawi } \\
\text { Kab. Bojonegoro } \\
\text { Kab. Tuban } \\
\text { Kab. Lamongan } \\
\text { Kab. Gresik } \\
\text { Kab. Bangkalan } \\
\text { Kab. Sampang } \\
\text { Kab. Pamekasan } \\
\text { Kota Blitar } \\
\text { Kota Surabaya }\end{array}$ & 1 & $\mathrm{X} 1$ \\
\hline $\begin{array}{l}\text { Kab. Malang } \\
\text { Kab. Lumajang } \\
\text { Kab. Jember } \\
\text { Kab. Probolinggo }\end{array}$ & $\begin{array}{l}\text { Kab. Pasuruan } \\
\text { Kab. Sidoarjo } \\
\text { Kota Malang } \\
\text { Kota Probolinggo }\end{array}$ & $\begin{array}{l}\text { Kota Pasuruan } \\
\text { Kota Mojokerto } \\
\text { Kota Batu }\end{array}$ & 2 & X1,X3 \\
\hline $\begin{array}{l}\text { Kab. Ponorogo } \\
\text { Kab. Nganjuk }\end{array}$ & $\begin{array}{l}\text { Kab. Madiun } \\
\text { Kab. Magetan }\end{array}$ & $\begin{array}{l}\text { Kota Kediri } \\
\text { Kota Madiun }\end{array}$ & 3 & $\mathrm{X} 1, \mathrm{X} 2$ \\
\hline $\begin{array}{l}\text { Kab. Kep. Seribu } \\
\text { Kota Jakarta selatan } \\
\text { Kota Jakarta timur } \\
\text { Kota Jakarta pusat } \\
\text { Kota Jakarta barat } \\
\text { Kota Jakarta utara } \\
\text { Kab. Bogor } \\
\text { Kab. Sukabumi } \\
\text { Kab. Cianjur } \\
\text { Kab. Bandung } \\
\text { Kab. Garut } \\
\text { Kab. Tasikmalaya } \\
\text { Kab. Ciamis } \\
\text { Kab. Kuningan } \\
\text { Kab. Cirebon } \\
\text { Kab. Majalengka } \\
\text { Kab. Sumedang }\end{array}$ & $\begin{array}{l}\text { Kab. Indramayu } \\
\text { Kab. Subang } \\
\text { Kab. Purwakarta } \\
\text { Kab. Karawang } \\
\text { Kab. Bekasi } \\
\text { Kab. Bandung Barat } \\
\text { Kota Bogor } \\
\text { Kota Sukabumi } \\
\text { Kota Bandung } \\
\text { Kota Cirebon } \\
\text { Kota Bekasi } \\
\text { Kota Depok } \\
\text { Kota Cimahi } \\
\text { Kota Tasikmalaya } \\
\text { Kota Banjar } \\
\text { Kab. Cilacap } \\
\text { Kab. Banyumas }\end{array}$ & $\begin{array}{l}\text { Kab. Purbalingga } \\
\text { Kab. Pekalongan } \\
\text { Kab. Pemalang } \\
\text { Kab. Tegal } \\
\text { Kab. Brebes } \\
\text { Kota Tegal } \\
\text { Kab. Kediri } \\
\text { Kab. Mojokerto } \\
\text { Kab. Jombang } \\
\text { Kab. Pandeglang } \\
\text { Kab. Lebak } \\
\text { Kab. Tangerang } \\
\text { Kab. Serang } \\
\text { Kota Tangerang } \\
\text { Kota Cilegon } \\
\text { Kota Serang } \\
\text { Kota Tangerang Slt }\end{array}$ & 4 & $\mathrm{X} 1, \mathrm{X} 2, \mathrm{X} 3$ \\
\hline $\begin{array}{l}\text { Kab. Banyuwangi } \\
\text { Kab. Bondowoso }\end{array}$ & Kab. Situbondo & Kab. Sumenep & 5 & X1,X2,X3,X7 \\
\hline
\end{tabular}




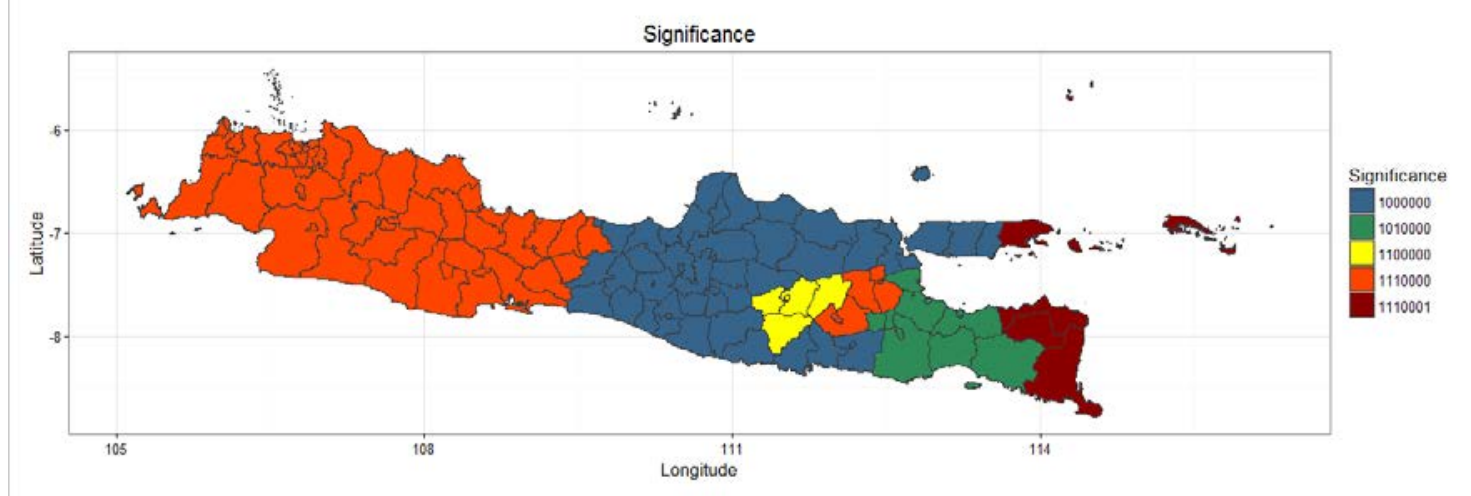

Gambar 2. Peta Hasil Pengelompokan Kabupaten/Kota berdasarkan Variabel yang signifikan

Tabel 6. Perbandingan AIC dan Devians Regresi Poisson, Regresi Binomial Negatif dan GWNBR

\begin{tabular}{ccc}
\hline Model Regresi & AIC & Deviance \\
\hline Regresi Poisson & 5803.768 & 4998.129 \\
Regresi Binomial Negatif & 1369.409 & 124.4262 \\
GWNBR Kernel Tetap Gaussian & 696.5925 & 32.88764 \\
\hline
\end{tabular}

\section{KESIMPULAN}

Setelah membandingkan keempat fungsi pembobot, model terbaik berdasarkan nilai AIC dan Deviance dihasilkan ketika pembobot yang digunakan untuk data kematian bayi di Pulau Jawa 2012 adalah Kernel tetap Gaussian. Kemudian GWNBR kernel tetap Gaussian juga memberikan hasil yang lebih baik dibanding regresi Poisson dan regresi Negatif Binomial untuk pemodelan data kematian bayi berdasarkan nilai AIC dan Deviance.

\section{DAFTAR PUSTAKA}

Afri, L. E., 2013, Model Regresi Binomial Negatif Terboboti Geografis Untuk Data Kematian Bayi. Jurnal Edu Research, 2(1), pp 15-26.

Akaike, H., 1974, A New Look at The Statistical Model Identification. Automatic Control, IEEE Transactions on, 19(6), pp 716-723.

Anselin L., 1988, Spatial Econometrics: Methods and Models. Dordrecht: Kluwer Academic Publishers.

Astuti, E. T., 2006, Uji Trend/Regresi untuk Data Over Dispersi, Jurnal Statistika Ikatan Perstatistikan Indonesia, 2, pp 179-186.

Bidanset, P. E., dan Lombard, J. R., 2014, The Effect of Kernel and Bandwidth Specification in Geographically Weighted Regression Models on The Accuracy and Uniformity of Mass Real Estate Appraisal, Journal of Property Tax Assessment \& Administration, 11(3), 5. 
Charlton, M., dan Fotheringham, A. S., 2009, Geographically Weighted Regression. White paper, National Centre for Geocomputation National University of Ireland Maynooth.

Dobson, A. J., dan Barnett, A., 2008, An Introduction to Generalized Linear Models. CRC press.

Fotheringham, A. S., Brunsdon, C., dan Charlton, M., 2002, Geographically Weighted Regression: The Analysis of Spatially Varying Relationships. John Wiley \& Sons.

Giuffrè, O., Granà, A., Roberta, M., dan Corriere, F., 2011, Handling Underdispersion in Calibrating Safety Performance Function at Urban, Four-Leg, Signalized Intersections. Journal of Transportation Safety \& Security, 3(3), pp 174-188.

Chiu, S.L., 1994, Fuzzy Model Indentification Based on Cluster Estimation, Journal of Intelligent and Fuzzy Systems, Vol. 2, pp 267-278.

Gollini, I., Lu, B., Charlton, M., Brunsdon, C., and Harris, P., 2015, GW Model: an R Package for Exploring Spatial Heterogeneity Using Geographically Weighted Models. arXiv preprint arXiv:1306.0413.

Gujarati, N. D., 1995, Basic Econometrics 3rd Edition. McGaw Hill, New York.

Guo, L., Ma, Z., and Zhang, L., 2008, Comparison of Bandwidth Selection in Application of Geographically Weighted Regression: a Case Study. Canadian Journal of Forest Research, 38(9), pp 2526-2534.

Hardin, J. W., Hilbe, J. M., dan Hilbe, J., 2007, Generalized Linear Models and Extensions. Stata Press.

McCullagh, P., dan J. A. Nelder, 1989, Generalized Linear Models, 2nd Ed., Chapman and Hall, New York.

Myers RH., 1990, Classical and Modern Regression with Applications Second Edition, PWS-KENT, New York.

Pratama, W., dan Wulandari, S. P., 2015, Pemetaan Dan Pemodelan Jumlah Kasus Penyakit Tuberculosis (TBC) di Provinsi Jawa Barat Dengan Pendekatan Geographically Weighted Negative Binomial Regression (GWNBR). Jurnal Sains dan Seni ITS, 4(1), D37-D42.

Rahmawati, R., dan Djuraidah, A., 2010, Regresi Terboboti Geografis dengan Pembobot Kernel Kuadrat Ganda untuk Data Kemiskinan di Kabupaten Jember. In Forum Statistika dan Komputasi, Vol. 15, No. 2.

UNICEF Indonesia, 2012, Kesehatan Ibu \& Anak. Jakarta: UNICEF Indonesia.

Widarjono, A., 2007, Ekonometrika Teori dan Aplikasi untuk Ekonomi dan Bisnis, Edisi Kedua, Penerbit Ekonisia Fakultas Ekonomi UII, Yogyakarta.

Widodo. T.C, Sunaryo. S, dan Purhadi, 2013, Pemodelan Spasial Balita Gizi buruk dengan Geographically Weighted Negative Binomial Regression dan Flexibly Shaped Spatial Scan Statistic. Surabaya: ITS [Thesis]. Tidak dipublikasikan. 